\title{
Dansksindede sønderjyske krigsdeltagere og faldne i Første Verdenskrig
}

En diskussion

\section{af Jorgen Kühl og Jens Ødegaard}

Der hersker nogen usikkerhed om, hvor mange danske sønderjyder der deltog og faldt på tysk side i Forste Verdenskrig.

Der er forskel mellem danske og tyske opgivelser, og det fremgår ikke altid helt éntydigt af tallene, om de omfatter både dansksindede og tyske eller kun de danske. Det er også uklart, hvorvidt opgivelserne dækker hele Sønderjylland/Slesvig mellem Kongeåen og Ejderen eller blot Nordslesvig, det nuværende Sønderjyllands Amt.

I denne artikel opsummeres, hvad der kan udledes om spørgsmålet fra almindeligt tilgængelige kilder - og det påvises, at tabstal og de faldnes nationale fordeling er usikre.

\section{Deltagere}

I litteraturen nævnes gang på gang et antal på 30.000 krigsdeltagere; men om det her drejer sig om dansksindede sønderjyder, nordslesvigere, danske nordslesvigere eller blot danske er mindre klart. Hvor f.eks. Rerup taler om "ca. 30.000 nordslesvigere «', der altså også må omfatte tyskere, skriver Buch og Petersen afgjort om »over 30.000 dansksindede sønderjyder $\aleph^{2}$, hvor betegnelsen sønderjyder må omfatte danske $i$ hele Slesvig; ligeledes anfører Lammers i Gyldendals Danmarks Historie, at "godt 30.000 danske mænd blev indkaldt $~^{3}$. Med andre ord er tallet det samme, men der er tale om forskellige geografiske områder. Muligvis skyldes denne forskel dog bare, at forfatterne bruger forskellige betegnelser uden dermed at lægge forskellig geografi til grund.

Såfremt det hos Rerup virkelig drejer sig om danske og tyske nordslesvigere, må de andres tal enten være helt forkerte, eller de må medregne et uforholdsvist stort antal danske syd for den nuværende grænse - forudsat, at Rerups skøn er korrekt.

De tidligste talopgivelser synes at stamme helt tilbage fra krigens tid, hvor rigsdagsmand H.P.Hanssen $i$ et dagbogsnotat den 3.12.1915 nævner, at "der er indkaldt ca. 30.000 danske Sønderjyder ${ }^{4}$. Knap tre år senere gentager Rørdam indirekte det samme tal: »Tallet på de Sønderjyder, der i denne Krig 
er faldne som tyske Soldater, nærmer sig nu det sjette Tusende, eller en Femtedel af hele den fra Nordslesvig indkaldte Styrke «s. Heller ikke hos Rørdam fremgår det éntydigt, om der kun menes danske.

Godt 20 år efter krigen kunne Morten Kamphövener fastslå, at »det danske Folk sendte 22500 Soldater i Verdenskrigen for at kæmpe for en Sag, som ikke var deres .... $\ll^{6}$. Dette tal ligger langt under de tidligere anførte opgivelser. Hvorledes han er nået frem til dette ret nøjagtige resultat, der jo omfatter alle danske i tysk krigstjeneste, er uvist; men netop dét, at det udgør $3 / 4$ af de i øvrigt opgivne tal på 30.000, kunne give anledning til at tro, at Kamphövener har lagt afstemningsresultatet i Nordslesvig i 1920 (ca. $75 \%$ danske) til grund for sit skøn. Såfremt denne antagelse er rigtig, indebærer det, at tallet på ca. 30.000 krigsdeltagere fra Nordslesvig ikke kan være helt misvisende.

Ud fra det foreliggende materiale er det ikke muligt endegyldigt at fastslå, hvor mange dansksindede der deltog i krigen på tysk side. Den største mangel ved materialet er, at det for det første ikke oplyses, hvor tallene stammer fra (dvs., hvilken autoritativ kilde der er lagt til grund); for det andet gøres der ikke rede for den metode, der er anvendt. For så vidt kan såvel de ca. 30.000 som de 22.500 - eller ingen af størrelserne - passe. Forudsat, at Kamphöveners tal er fremkommet efter den ovenfor skitserede metode og tager udgangspunkt i de gængse opgivelser, kunne noget følgelig tyde på, at opgivelsen på 30.000 tyske og danske krigsdeltagere er det omtrentlige faktiske tal for Nordslesvig.

For at finde frem til det præcise tal, vil det være påkrævet først ved hjælp af den prøjsiske lægdsrulle at bestemme det samlede antal indkaldte i området; derefter bør man ved en sindelagsundersøgelse søge at fastslå den enkelte soldats nationale tilhorsforhold; men det sidste er ganske enkelt ikke muligt, hvorfor en opdeling efter nationalitet må forblive et yderst usikkert skøn.

\section{Faldne}

Heller ikke antallet af faldne er nøjagtigt opgjort: dels er der forskel mellem danske og tyske opgivelser, dels varierer de danske tal.

Fra tysk side har Alnor beregnet, at 5136 nordslesvigske (tyske og danske) soldater mistede livet $\mathrm{i}$ eller som følge af krigen ${ }^{7}$. Tallet beror på oplysninger fra de enkelte sognes mindesmærker over de faldne ${ }^{8}$.

For at kunne fastslå andelen af hhv. tyske og danske faldne har Alnor $i$ halvdelen af de nordslesvigske sogne ved hjælp af lokale, der havde et godt kendskab til de faldne, søgt at fastslå deres nationale sindelag. Han sondrede mellem tre kategorier: tyske, danske eller ubestemmelige. "Ved disse fordelinger er anvendt den største forsigtighed, og en faldet er kun regnet som tysk, hvis 


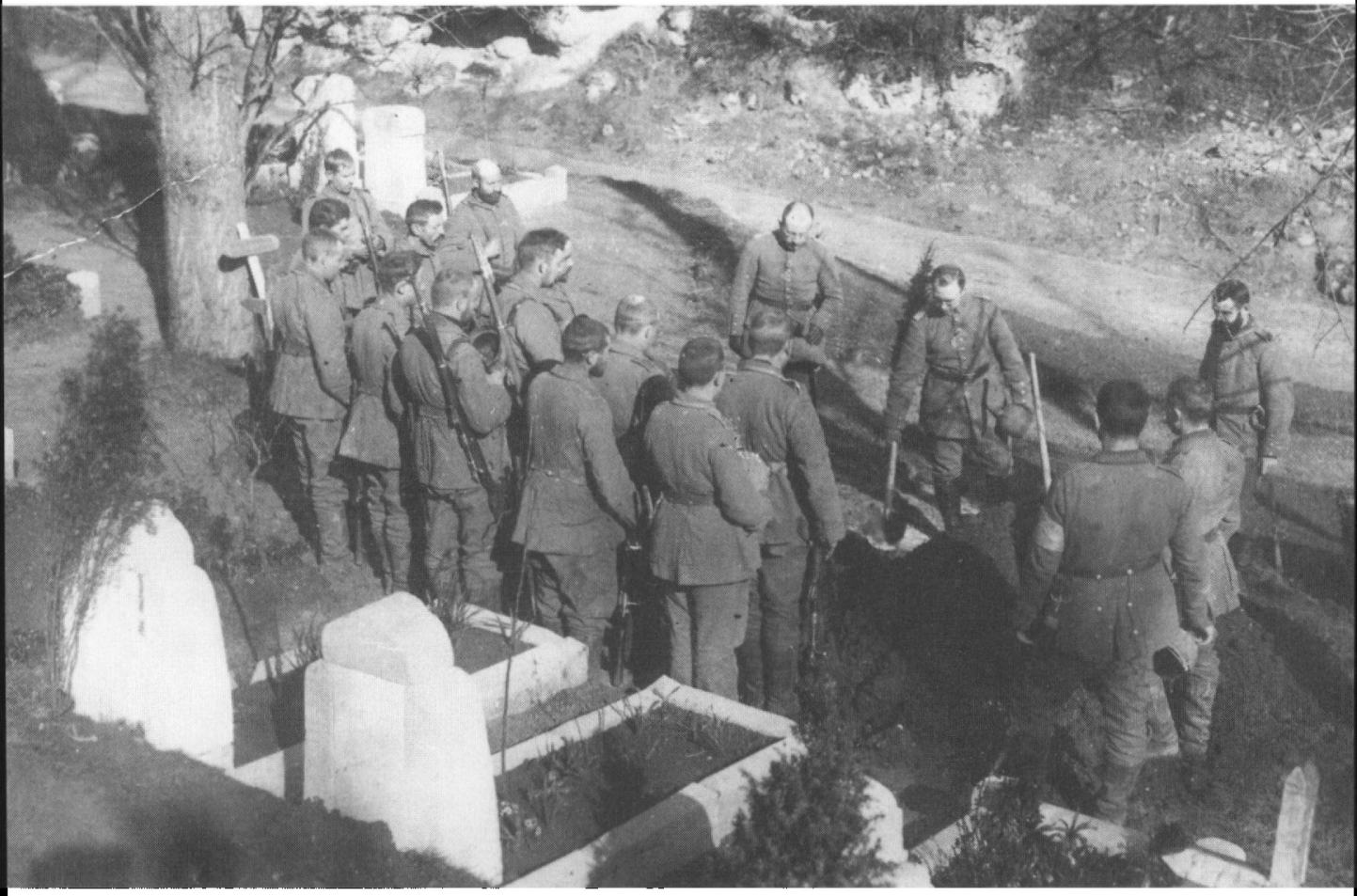

Omkring 5000 faldne soldater fra Nordslesvig fandt en grav i det fremmede under 1. Verdenskrig. I 1915 blev Hans Christoph Sohl, son af kobmand Sohl i Haderslev, begravet på kirkegärden i Moulin $i$ Nordfrankrig. Historiske Samlinger for Sonderjylland.

hans tyske sindelag blev fastslået uden tvivl«?. Herved blev ikke hjemmets, mens derimod den faldnes nationale sindelag forsøgt fastslået.

Hans undersøgelse af 59 af $\mathrm{i}$ alt 117 nordslesvigske sogne giver det resultat, at ud af 2781 faldne var $1285(46 \%)$ tyske, $1422(51 \%)$ danske samt $74(3 \%)$ ubestemmelige $^{10}$. "De samlede danske tab ligger altså under 3000 , og det er $\mathrm{i}$ den sammenhæng helt uden betydning, om man dertil lægger nogle tab fra den meget ubetydelige danskhed i Mellemslesvig før eller under krigen “" .

I et forsøg på at imødegå Alnors tidligere offentliggjorte samlede tal på ca. 3000 danske faldne fra Nordslesvig påpegede Kamphövener i $1927^{12}$ først, at det ville være påkrævet at undersøge samtlige nordslesvigske sogne for at nå det endelige resultat; dernæst betonede han, at den af Alnor gennemførte sindelagsundersøgelse ikke kunne give noget nøjagtigt resultat; endelig fremhævede han, at der ikke var blevet taget hensyn til de mellemslesvigske dansksindede. 


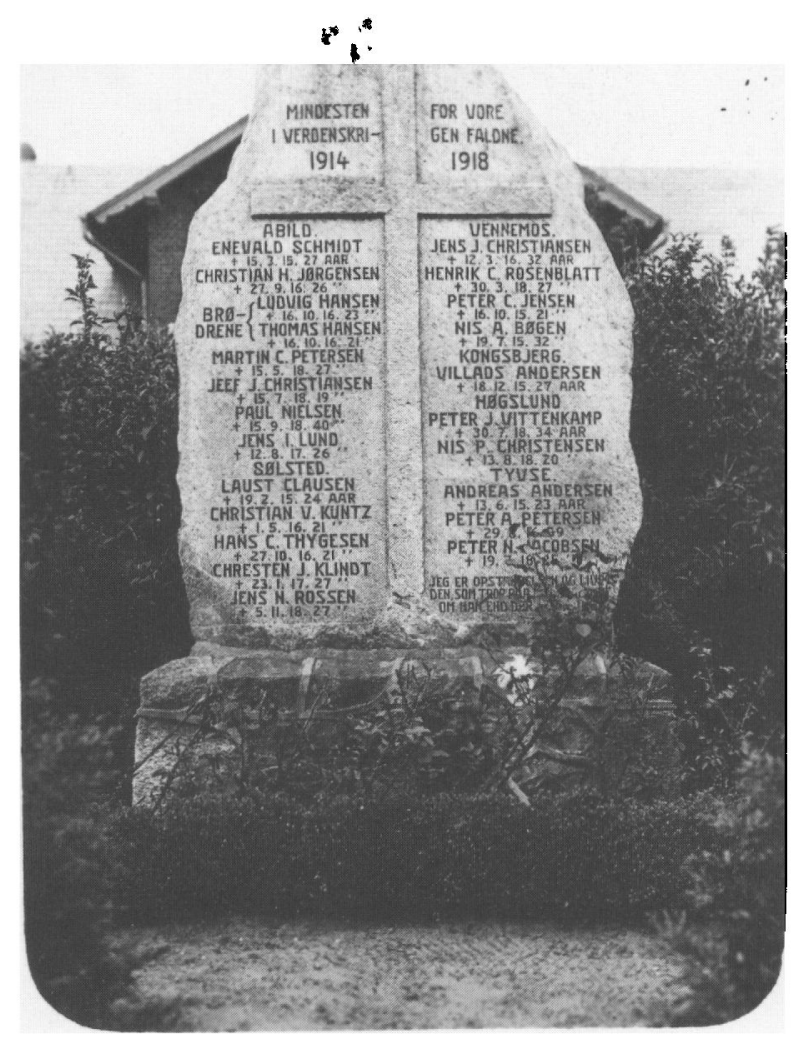

Kamphöveners indvendinger er relevante af følgende grunde:

1) Det er ikke givet, at de sogne, Alnor har anvendt i sin sindelagsundersegelse, er repræsentative for hele Nordslesvig. Således er det tænkeligt, at der er indgået en vægtning til fordel for den ene side. Her spiller det en rolle, hvilke lokale personers oplysninger han baserer sin undersøgelse på, og hvad Alnor helt præcist bad disse om at undersøge. Det vides ikke, om de respektive personer var danske, hjemmetyske eller ubestemmelige; men under alle omstændigheder kan de som lokale ikke have været helt uvildige i kategoriseringen. Blandt andet må der tages højde for, at de nationale spændinger i 1920erne - hvor tyskerne arbejdede for en grænserevision, og hvor danskerne hævdede afstemnings-resultatet fra 1920 - kan have påvirket den bagudvendte sindelagsbestemmelse i tysk eller dansk favør. 


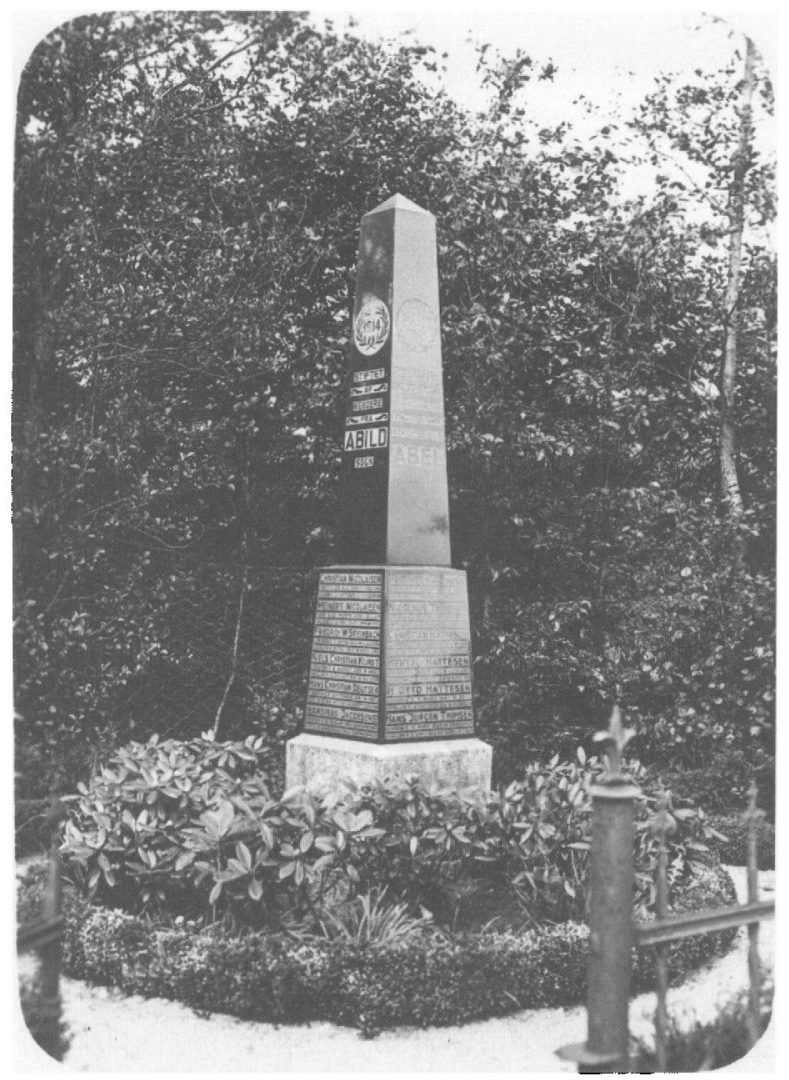

Mindesten $i$ hvert eneste sogn $i$ Sonderjylland beretter om de faldne i I. Verdenskrig. Abild sogn ved Tonder fik to sten-fordi nogle faldne var danske, andre tyske. Stenene blev opsat syd for prostegärdshaven. Den danske sten (venstre side) barer 23 navne, den tyske (højre side) 12 navne. Den tyske sten har både dansk og tysk tekst. Historiske Samlinger for Sonderjylland.

2) Det vides ikke, hvilket kendskab de lokale undersøgere havde til de faldne. Ifølge Alnor selv blev der ikke taget hensyn til hjemmets sindelag, men udelukkende til den enkeltes. Betyder det da, at hjemmet ikke blev adspurgt om den faldnes sindelag - og hvem eller hvad tjente så som kilde?

3) I og med, at kun de, som helt afgjort var tyske, blev talt som tyske, kunne man forvente en væsentlig større andel af ubestemmelige end de af Alnor opgiorte $3 \%$. At det ikke er tilfældet tyder på, at undersøgerne enten skelnede skarpt mellem tysk og dansk, eller at der vitterlig ikke var flere tvivlstilfælde. Det kan betvivles, at den nationale bevidsthed var så klar i 1914 , som resultatet af undersøgelsen efter 1920 indikerer. Tværtimod kan det 
antages, at nationaliteten først blev bevidstgjort under indtryk af dels på tysk side nederlagsstemningen efter krigen, dels fra dansk side genforeningshåbet samt endelig den nationale agitation fra begge sider op til afstemningen i 1920.

4) Såfremt nationaliteten i 1914 virkelig var så klar, som de 3\% ubestemmelige kunne tyde på, synes det - sammenholdt med afstemningsresultatet $\mathrm{i}$ $1920^{13}$ - bemærkelsesværdigt, at hele $46 \%$ af de faldne var tyske. Enten blev der indkaldt og faldt forholdsvis flere tyske end danske (hvilket der ikke er noget, som tyder på) - eller en del af de tysksindede i 1914 må være blevet danske i 1920, og i så fald var nationaliteten ikke klart bestemt.

Forudsat, at 1. afstemningstallet for $1920 \mathrm{kan}$ overføres til den nationale lagdeling i 1914 (hvilket er tvivlsomt), at 2. der dengang ikke var større alders- eller kønsforskel mellem dansk- og tysksindede nordslesvigere, at 3. indkaldelsesfrekvensen var identisk for danske og tyske, samt at 4. dødshyppigheden i krigen var lige stor for danske og tyske deltagere, vil et rimeligt skøn for antallet af faldne dansksindede nordslesvigere være på ca. $75 \%$ af 5136 faldne $=$ ca. 3850 danske. Dette tal er ikke så lidt større end Alnors resultat.

5) Sluttelig er det ikke indlysende, at antallet af dansksindede faldne fra Mellemslesvig (Zone II) er »fuldstændig uden betydning«. Når afstemningsresultatet fra $1920,{ }^{14}$ med de forbehold, som er anført under ovenstående punkt $3)$, lægges til grund, er det rimeligt at antage, at der må have befundet sig en del dansksindede blandt de 4780 faldne fra Mellemslesvig ${ }^{15}$. Hvor mange, det drejer sig om, er uvist, men når vi groft beregner antallet med samme betingelser og forudsætninger som oven for, vil et skøn på over 900 faldne dansksindede ikke kunne være helt forkert. Ydermere kan det formodes, at der ligeledes var (enkelte) danske blandt de faldne fra området syd for Zone II, der jo slet ikke nævnes i Alnors undersøgelse.

Det samlede antal af dansksindede krigsdeltagere - som Alnor jo sætter til højst 3000 - ligger ifølge Kamphövener "maaske snarere over 4.000. Men noget bestemt Tal kan, som næunt, ikke opgives, før der foreligger en samlet Redegørelse ... $\ll^{16}$. Intet tyder på, at en sådan samlet opgørelse nogen sinde er blevet foretaget. Ikke desto mindre kunne Kamphövener 10 år senere tale om, at 4500 dansksindede soldater måtte lade livet $i$ krigen ${ }^{17}$. Igen gælder her som ved hans opgivelse af antal deltagere -, at tallet svarer forbløffende præcist til 75\% (lig afstemningsresultatet i Zone I) af de gængse danske talstørrelser på 6000 faldne.

Fra dansk hold er opgørelserne mindre nøjagtige. Rerup nævner både Alnors opgørelse af 5136 og danske beregninger på ca. 6000 faldne fra »det dansktalende Slesvig « ${ }^{18}$. Såvel Lammers som Buch og Petersen taler om godt 5000 
faldne danske ${ }^{19}$. Fangel anfører derimod 5300 faldne nordslesvigere ${ }^{20}$. I ingen af fremstillingerne gøres der rede for, hvordan de respektive tal er beregnet.

Det tidligste skøn over faldne danske finder vi hos Rørdam, der i september 1918 skriver, at antallet af faldne sønderjyder nærmer sig $6000^{21}$. Den 29.12.1918 omtalte en vis pastor Storm under mindegudstjenesten for Verdenskrigens faldne i Elizabeths Kirken i København 6000 faldne dansktalende sønderjyder ${ }^{22}$.

I slutningen af juni 1919 blev der ved et ungdomsmøde på Skamlingsbanken nævint to talstørrelser: Først talte sagfører Tranberg Jensen fra Odense om, at omtrent 7000 danske sønderjyder havde mistet livet i krigen; senere sagde folketingsmand N. Neergaard: „Over 6000 Sønderjyder, der kæmpede for deres Undertrykkere, er faldne ${ }^{23}$. For alle disse tal gælder, at det drejer sig om skøn, der end ikke søges sandsynliggjort.

I mangel af bedre må vi tage udgangspunkt i Alnors undersøgelse, eftersom han er den eneste, der blot tilnærmelsesvist gør rede for sin beregningsmetode. Antallet på 5136 faldne nordslesvigere synes rimeligt, da mindesmærkerne må antages så vidt muligt at medtage alle de pågxldende sognes faldne uanset nationalitet. Fra hele Slesvig faldt $16538^{24}$ krigsdeltagere. Hvor mange dansksindede krigsdeltagere, det alt $i$ alt drejer sig om, vides ikke; men ifølge vor skitserede beregning, som må tages med de nævnte forbehold, kommer tallet til at ligge mellem 4500 og 5000 faldne.

Af ovenstående drøftelser følger, at såvel Alnors sindelagsundersøgelse som de udokumenterede danske skøn må anses for at være usikre. I betragtning af den specielle grænselandsproblematik, hvor nationalt sindelag ofte er en flydende størrelse, er det næsten umuligt at fastslå den enkelte deltagers nationalitet - og da slet ikke ved en bagudvendt sindelagsundersegelse. Derfor er det forsvarligt at nævne de faldne nordslesvigere under ét og blot konstatere, at en betydelig del af dem var dansksindede.

\section{LITTERATUR}

K. Alnor: Handbuch zur schleswigschen Frage, vol. II, u.å.

J.Buch og P.Petersen: Den nationale kamp i Sønderjylland 1864-1920. Amtscentralen for undervisningsmidler 1982.

V.la Cour m.fl. (red.): Sønderjyllands Historie, vol. V, Tidsrummet 1864-1920. København u.å.

H. Fangel: Nordslesvig under første verdenskrig 1914-18, s. 2-11 i: Pluk fra forskning i Sønderjylland, 2, 1984.

Flensborg Avis

"Folkung "s Gransearkiv, August 1937.

H.P.Hanssen: Fra Krigstiden. Dagbogsoptegnelser, vol. I. København 1924.

Hejmdal 
K.C.Lammers: 1914-1920. Fra borgfred til Påskekrise, s. 82-138 i: S.Morch (red.): Danmarks Historie, bind 7, Tiden 1914-1945. København 1988.

L.Rerup: Slesvig og Holsten efter 1830. København 1982.

V.Rordam (ed.): Sønderjyden Mikael Steffensen En af de Faldne. København 1918.

\section{NOTER OG HENVISNINGER}

1. Rerup 1982, s. 301.

2. Buch og Petersen 1982, s. 39.

3. Lammers i Gyldendals Danmarks Historie 7, 1988, s. 87.

4. Hanssen 1924, vol. I, s. 156 (Berlin, 3.12.1915).

5. Rørdam 1918, s. 5 (forordet fra september 1918).

6. "Folkung«s Grænsearkiv, August 1937: den årlige mindefest i Fredericia for udfaldet fra den gamle fæstningsby den 6. juli 1849, hvor Kamphövener holdt tale den 6.7.1937.

7. Alnor, s. 848 ff.

8. ibid., s. 848, note 3 . Ved den samtidigt gennemforte beregning for den tyske del af SlesvigHolsten blev tallene beregnet af de folkeregistrerende myndigheder (Standesämter). I Egernførde sogn blev begge fremgangsmåder brugt; det viste sig, at sogneopgivelserne lå en smule over de af det offentlige registrerede tal.

9. ibid., s. 850.

10. ibid., s. 852.

11. ibid.

12. Hejmdal, 16. +17.3 .1927 : En eneste var for mange«. En tysk Redegørelse for Tallet af de faldne danske Sønderjyder, - og en Imødegaaelse. Af Morten Kamphövener.

13. Ved afstemningen i Zone I den 10.2.1920 stemte 75.431 for Danmark og 25.329 for Tyskland.

14. Ved afstemningen i Zone II den 14.3.1920 stemte 51.724 for Tyskland og 12.800 for Danmark.

15. Alnor, s. 848ff.; tallene er for Flensborg, Flensborg Land (der rækker lidt uden for Zone II i det nordlige Angel) og Sydtønder Amter.

16. Se note 12.

17. »Folkung«s Grænsearkiv, August 1937 (se note 6).

18. Rerup 1982, s. 302; næsten ordret i Sønderjyllands Historie, s. 269.

19. Lammers i Gyldendals Danmarks Historie 7, 1988, s. 87; Buch og Petersen 1982, s. 39.

20. Fangel 1984, s. 11.

21. Rørdam 1918, s. 5 (jvf. note 5).

22. Refereret i Flensborg Avis, 3.1.1919.

23. ibid., 1.7.1919.

24. Alnor, s. 848ff.: Sammentalling af tabstallene for Nordslesvig og amterne Husum, Sydtønder, Egernførde, Rensborg, Ejdersted, Flensborg Land, Flensborg samt Helgoland. Ikke medregnet er her de i krigen faldne 7986 ( 4925 hærsoldater, 3061 marinere) soldater, som var stationerede i Kiel; heriblandt befandt der sig muligvis nogle indkaldte, der var hjemmehørende i Sønderjylland. Hertil kom adskillige ved garderregimenterne i Berlin og ved marinen, især fra Vestkysten. 